\title{
Augmenting realm of 3D printing in restorative dentistry and endodontics: a review
}

\author{
Nikita Arun Kamat ${ }^{1,{ }^{*},}$, Saritha Vallabhaneni' ${ }^{2}$, Prahlad Saraf ${ }^{2}$, Sandhya Khasnis ${ }^{2}$ \\ ${ }^{1}$ Postgraduate Student, Department of Conservative Dentistry \& Endodontics, PMNM Dental College, \\ Bagalkot, Karnataka, India . \\ 2Professor, Department of Conservative Dentistry \& Endodontics, PMNM Dental College, Bagalkot, \\ Karnataka, India .
}

\section{N F O R M A T I O N}

\section{Article History}

Received $2^{\text {nd }}$ February 2020

Received revised

$6^{\text {th }}$ March 2020

Accepted $6^{\text {th }}$ March 2020

Available online

9th March 2020

\section{K E Y W O R D S}

3D printing

CAD-CAM

Fused deposition modelling

Stereolithography

\section{A B S T R A C T}

The 3D printing is entrenching itself as an advancing forefront in the field of dentistry. The 3D printing technology mostly works on the concept of additive manufacturing, which has its advantages over in contrast to the subtractive manufacturing process. Advancement of this technology has improved diagnostic accuracy, easy treatment delivery and reduced chair side time allowing the dentist to provide treatment effectively and with high precision. Educational programs which utilise 3D printed models stimulate better training of dental skills in students and trainees. Thus, 3D printing enables to provide a holistic approach to ameliorate the health and wellbeing of patients. This review article provides an overview of different methods of 3D Printing and its applications focusing on Restorative dentistry and Endodontics.

\section{Introduction}

Digitalization through 3D printing is a remarkable advancement in the field of dentistry which allows precision in treating patients. It is as an emerging technology with its wide variety of applications in the dental field. In the present Era, this technology ensures quality and quantity in dental care, making it a preferred modality of treatment [1].

Charles Hull printed a three-dimensional object in 1983 for the first time. He then invented the first 3D printer which he named "stereolithography". Initially, 3D printing has been encompassing the fields of architecture, aeronautics and telecommunications. Later its application in the medical and dental field became a subject of great interest leading to increased research and better results [2].

Three-dimensional (3D) printing can be precisely described as additive manufacturing (AM), rapid prototyping, layered manufacturing or solid-free form fabrication. It is the process in which, with the creation of a virtual design of the object, the three-dimensional model is sliced into multiple thin layers. These sliced 3D models are then transferred into the 3D printer of compatible brand and type via USB, SD or Wi-Fi. The 3D printer converts every slice (2D image) into a three-dimensional object. Any geometrical object can be created by this technology $[1,3]$. 


\subsection{How different is $3 D$ printing from CAD-CAM technology?}

CAD-CAM uses subtractive manufacturing techniques like milling, which has some limitations in relation to $3 \mathrm{D}$ printing. Milling creates a large amount of raw waste material due to its unused portions of the mono -blocks which have to be discarded after milling. Also, the recycling of excess ceramic is not feasible. Microscopic cracks can be introduced in the ceramic during the process of machining due to their brittle nature. Milling tools are usually prone to heavy abrasion and wear [4].

\subsection{Applications of 3D printing technology in dentistry}

Its various applications in dentistry include; Fabrication of 3D printed tooth, implant-supported restorations, Composite and Ceramic esthetic inlays and onlays, Guided Endodontic interventions, Customized myofunctional appliances, Maxillofacial customised prosthesis like eye or nose prosthesis, Obturator for maxillectomy, complete Dentures, digital impressions, invisaligners orthodontic braces, Bioprinting tissue or organs and also customised 3D printed dosage delivery system. Thus, 3D printing has revolutionized dentistry while able to produce high-quality dental prosthesis with precision.

\section{Review of Various methods of $3 D$ printing}

\subsection{Stereolithography}

Charles Hull invented Stereolithography device in the 1980s. This device became a commercially popular printer for rapid prototyping. It depends on additive manufacturing, which converts photosensitive monomer resin (liquid material) into polymer resin (solid) layer by layer by curing them using an ultraviolet light source through photopolymerization. The materials used must be photo-curable like acrylics, epoxies, fabrication of titanium implants. The self-adhesive property of the material causes the layers to bond to one another and eventually form a complete, 3D object. The dynamics involved in the procedure affect the polymerisation time and the thickness of the layer that is cured. The addition of UV absorbers can control the depth of the polymerisation. This process is used in making Implant guides and surgical stents $[5,6]$.
Schott C Rump developed Fused Deposition Modelling. A thermoplastic filament material is delivered through a nozzle controlled by temperature, and the material hardens immediately within 1 sec after extrusion. The motion of material is computer-controlled, and it deposits the material is an extremely thin layer on to a subsidiary platform. Materials such as polycarbonates and polysulfones are used. The speed and the travel of the extruder, the flow of material and the size of each 'step' influence the accuracy. This deposition modelling is the process that is used by most low cost 'home' $3 \mathrm{D}$ printers. It is used for printing anatomical models without any complexity $[7,8]$.

\subsection{Selective laser sintering}

This technology was developed by the University of Texas and brought into use since the mid-1980. A fine material powder is sintered by scanning laser, to build up structures incrementally. As a powder bed drops down, a new fine layer of material is spread uniformly over the surface. A high $(60 \mu \mathrm{m})$ level of resolution may be obtained. No support material is required as the structures that are printed are supported by the surrounding powder. It is used in areas which require high fracture toughness and mechanical strength. Selective laser sintering is used in the fabrication of anatomical study models, cutting and drilling guides, dental models, and also for engineering/design prototypes [9].

\subsection{Photopolymer jetting}

Light sensitive polymers are laid onto a platform from an inkjet type print head and cured layer by layer on an incrementally descending platform with the dynamic print head. A support structure is laid down in a friable support material. This technology gives the resolution of approximately 16 microns and easy access for making complex and fine detailed objects. They are useful for printing dental or anatomical study models, Implant drill guides quickly as they are less bulky. Three-dimensional Jet printers may have a single print head like a computer printer, or they may have multiple heads to cover the width of the working platform. A UV lamp or a light source is used by $3 \mathrm{D}$ printers to harden the resin or wax after each layer is jetted. Either the print head moves across the working platform, or the platform moves back and forth under the stationary print head. A wide range of resins, silicone rubber and waxes are used for casting .

\subsection{Fused deposition modelling}

\subsection{Powder binder printer}


A modified inkjet head is used to print in this printing method. The liquid droplets are allowed to infiltrate a uniform and single layer of powder one after the other. With this, the powder bed drops incrementally, and a final model is ready. This model is built of many layers and a new fine layer of powder is swept over the surface. The un-infiltrated powder will itself support the model, and so no other support material is essential. A cyanoacrylate or epoxy resin can be infiltrated during post-processing procedures to improve the strength and surface hardness. These models are fragile, and their accuracy is limited; however, they are useful as study models or visual prototypes $[3,10]$.

\subsection{Thermal inkjet / bioprinting}

Ink-jet printing is a "noncontact" technique which uses thermal, electromagnetic or piezoelectric technology to deposit tiny droplets of ink onto a substrate. In inkjet printing, droplet deposition is usually done by using heat or mechanical compression to eject the ink drops. The print head is heated, which creates small air bubbles that collapse, creating pressure pulses that eject ink drops from nozzles in volumes as small as 10 to 150 picoliters. These are particularly promising for use in tissue engineering and regenerative medicine. Because of their digital precision, control, versatility, and benign effect on mammalian cells, this technology is already being applied to print simple 2D and 3D tissues and organs, also known as bioprinting. Bioprinting is used to create soft tissue scaffolds, 3-dimensional scaffolds, hydrogels, polymers [11].

\section{Applications of $3 \mathrm{D}$ printing in restor- ative dentistry and endodontics}

Three-dimensional printing has successfully improved the quality and precision of dental operative work. With this clinical dental practice has become easier, efficient and quick.

\subsection{Reconstruction of 3D models}

Dental education has always relied on extracted teeth for preclinical exercises, and these teeth provide semirealistic clinical situations. But there is always an uncertainty in availability of all possible anomalies in those extracted teeth. The 3D printed tooth models can mimic teeth with internal, external resorption defects, open apices and those with pulp stones, dilacerations, dens in dente and many other anomalies which serve as morerealistic anatomic structures, which aid in the development of endodontic skills by providing visual, acoustic and tactile proprioception and help in acquiring improved skills in minimal intervention during preclinical training. In 3D reconstruction, the 3D image of the teeth is taken, with which features of product or component are captured then they are uploaded to a computer software program, to get a copy of the same component. The desired model can be adjusted or altered as per the needed requirement and can be printed in a few hours. It reduces lead time for manufacturing rapid prototypes. Keeping in mind individual treatment objectives, a simulated 3D model of final treatment outcome can also be fabricated, for patient education and motivation which will enable patient to understand treatment options and strategy even before starting the procedure $[12,13]$.

\subsection{Fabrication of tooth restoration}

The common factor of failure of restorative materials is dimensional changes at the margins, which lead to instability or total loss of dental fillings. 3D restorative materials with continuous self-folding adjustment are materials which are capable of moving toward the peripheries by changing position and shape from the centre to margins; hence they avoid microleakage or marginal overhangs. These eliminate the need for Dental adhesives (etching-bonding systems) as they rely on mechanical retention rather than chemical aids. They can also be used in inaccessible areas where manipulation of restorative materials is difficult. For Fabrication of 3D printed tooth restoration, tooth cavity preparation is done, scanning of preparation is done. It is uploaded on the computer; filling with appropriate material of choice is chosen and printed. Lastly, cementation can be done. These materials have good strength and biocompatibility and maximum adaptation. Thus, it helps in improved esthetic treatment planning and better skill acquisition [14].

\subsection{Guided endodontics}

It's a novel treatment approach for root canal treatment of teeth with calcified canals for gaining access using 3D printed templates. Ageing, trauma, caries or orthodontics causes progressive narrowing of root canals and during attempted location and negotiation of calcified canals perforations or gauging are implicated. Hence to avoid this, 3D guided access stents or templates are digitally designed to target burs in elusive canals. CAD software Digital impressions are merged with CBCT scans, this forms DICOM data which is then 
allowed to create STL file containing bony architecture for pulp canal obliterated teeth, these structures are sliced, and the sliced data is sent to the printer where the final printed guides are obtained. 3D printed access guides are efficient and safe means for addressing challenging endodontic scenarios like malpositioned teeth or teeth with extensive restoration enabling conservation of tooth structure and minimizing chances of iatrogenic errors [15-17].

\subsection{Surgical guides}

Endodontic microsurgery like root-end resection and osteotomy procedures are done based upon on CBCT measurements or X-Ray. In clinical scenarios proper orientation, angulation and depth of penetration of bur are required which otherwise might cause deviation in angulation or larger diameter of osteotomy leading to human errors, increased healing time and post-operative pain which is undesirable. Surgical stent-like guides are designed that reproduces preplanned osteotomy site which can mitigate risk through avoiding encroachment upon neurovascular structures or adjacent teeth and also avoiding perforations at osteotomy sites. With these stents, more accurate, precise, localised, less invasive microsurgeries can be performed [16,17].

\subsection{Auto transplantation}

Successful auto transplantation requires preservation of periodontal ligament cells and adequate adaptation of transplanted tooth to the recipient site. In conventional methods, while preparation of the recipient site, multiple fitting attempts to alveolar bone are initiated that causes increased extra oral time. Any kind of trauma to PDL during the procedure profoundly influences the outcome results. Auto transplantation using 3D printing increases the chances of the tooth-saving procedure. Computer-aided rapid prototyping (CARP) is used to print a replica of the tooth such that modification of recipient bone site is done before extraction without PDL damage from repeated insertion and removal. With this recipient, the tooth can be prepared for the crown, and a temporary crown can be placed immediately after placing the tooth in the desired tooth site. This method minimises extra oral time and chances of any error during auto transplantation $[18,19]$.

\subsection{Dental pulp regeneration \& fabrication of scaffolds}

The 3D cell printing technique can also be utilized for replacing pulp tissue. Additive manufacturing has the capability to preserve natural tooth rather than replacing it by prosthetic surgery. Using an inkjet device by dispensing layers of cells that are suspended in the hydrogel, the structure of the pulp tissue is recreated, which mimics the natural pulp tissue of the tooth. This is achieved by systematically placing the odontoblastic cells at the periphery and fibroblasts within the core with a supportive network of vascular and neural cells. Various types of calcium phosphate cements have been developed by 3D printing to form porous customized scaffolds for regeneration of pulp dentin complex by Rapid prototyping or solid free form fabrication techniques. Polyethylene oxide and polyethylene glycol dimethacrylate photo-polymerisable hydrogels are used to fabricate scaffolds of various geometric shapes through customized tissue engineering. These 3D scaffolds are useful in repairing the defects caused by accidents, surgery or during birth $[20,21]$.

\section{Limitations of 3D printing}

- High cost.

- An inherent weakness is built into the design due to its staircase effect. This effect is created by successive deposition of material on top of the first layer.

- Requires support materials, which are difficult to remove later.

- Finishing the final product is time-consuming.

- It is technique sensitive; a trained professional is required.

- Resin causes inflammation, irritation on contact or inhalation.

- Resin cannot be heat sterilized.

- Stereolithography can be done if only light-curable polymers are available.

- Depending on materials, additional treatment like sintering might be required for additional strength

- Ethical and legal clearance is low.

\section{Conclusion}

Procurement and availability of technical expertise and equipment within endodontic practices present formidable obstacles to widespread deployment within the endodontic speciality. The 3D printing has enormous potential to ameliorate dental care in treatment, research and education. Thus, 3D printing is successful in establishing itself as a milestone in the field of dentistry, its utility in treatment planning and analysing 
Table 1. 3D Printing modalities

\begin{tabular}{|c|c|c|c|c|}
\hline 3D Printer & Materials & Applications & Advantages & Disadvantages \\
\hline $\begin{array}{l}\text { Steriolithogra- } \\
\text { phy } \\
\text { (SLA) }\end{array}$ & $\begin{array}{l}\text { Photopolymeris- } \\
\text { ing Resins , } \\
\text { Acrlyics \& Epox- } \\
\text { ies. }\end{array}$ & $\begin{array}{l}\text { Dental models, } \\
\text { surgical Guides, } \\
\text { orthodontic re- } \\
\text { tainer and align- } \\
\text { ers ,crowns and } \\
\text { bridges. }\end{array}$ & $\begin{array}{l}\text { High accuracy, } \\
\text { Good surface } \\
\text { finish, } \\
\text { high mechanical } \\
\text { strength, } \\
\text { rapid fabrication. }\end{array}$ & $\begin{array}{l}\text { High cost, cannot be heat } \\
\text { sterilized, } \\
\text { Limited shelf life, skin irri- } \\
\text { tation by resin contact or } \\
\text { inhalation. }\end{array}$ \\
\hline $\begin{array}{l}\text { Fused Deposi- } \\
\text { tion Modelling }\end{array}$ & $\begin{array}{l}\text { Thermoplastic } \\
\text { polymers like } \\
\text { Polylactic acid, } \\
\text { Polycarbonate, } \\
\text { Polyether Ether } \\
\text { Ketone, Poly Me- } \\
\text { thyl Methacry- } \\
\text { late, Bioactive } \\
\text { glass Compo- } \\
\text { sites. }\end{array}$ & $\begin{array}{l}\text { Bone tissue Engi- } \\
\text { neering, Craniofa- } \\
\text { cial Defects, } \\
\text { Maxillofacial Pros- } \\
\text { thetics } \\
\text { (prototyping ana- } \\
\text { tomical parts ) }\end{array}$ & $\begin{array}{l}\text { Most low cost 3D } \\
\text { printer. }\end{array}$ & $\begin{array}{l}\text { Limited materials - only } \\
\text { thermoplastic materials } \\
\text { can be used. } \\
\text { Limited shape complexici- } \\
\text { ty. } \\
\text { FDM requires support } \\
\text { structures to be removed. }\end{array}$ \\
\hline $\begin{array}{l}\text { Selective Laser } \\
\text { sintering. }\end{array}$ & $\begin{array}{l}\text { Polymer Powder } \\
\text { such as Alumide, } \\
\text { Polyamide, rub- } \\
\text { ber like polyure- } \\
\text { thane, } \\
\text { Metal alloys like } \\
\text { titanium ,Co-Cr, } \\
\text { stainless steel. }\end{array}$ & $\begin{array}{l}\text { Metal crown cop- } \\
\text { ings , metal or res- } \\
\text { in partial denture } \\
\text { framework, } \\
\text { Cutting drilling } \\
\text { guides. }\end{array}$ & $\begin{array}{l}\text { High fracture } \\
\text { toughness and } \\
\text { mechanical } \\
\text { strength. Poly- } \\
\text { meric metals can } \\
\text { be autoclaved. } \\
\text { metallic materi- } \\
\text { als can be recy- } \\
\text { cled. }\end{array}$ & $\begin{array}{l}\text { High cost, significant infra- } \\
\text { structure required. } \\
\text { messy powders with inha- } \\
\text { lation risk. } \\
\text { Explosive Risk. }\end{array}$ \\
\hline $\begin{array}{l}\text { Powder Binder } \\
\text { Printers }\end{array}$ & $\begin{array}{l}\text { Plaster of paris . } \\
\text { Pigmented water }\end{array}$ & $\begin{array}{l}\text { Study models, } \\
\text { Visual prototypes. }\end{array}$ & $\begin{array}{l}\text { Low cost, rela- } \\
\text { tively fast pro- } \\
\text { cess, materials } \\
\text { used are safe, } \\
\text { they can print } \\
\text { coloured 3D ob- } \\
\text { jects. }\end{array}$ & $\begin{array}{l}\text { Low resolution. } \\
\text { Limited Accuracy. } \\
\text { Less strength. } \\
\text { Difficult to heat sterilize. }\end{array}$ \\
\hline Bioprinting & $\begin{array}{l}\text { Alginate, ,fibrin, } \\
\text { collagen, } \\
\text { PLGA (poly lactic } \\
\text { co-glycolic acid), } \\
\text { tricalcium phos- } \\
\text { phate, chitosan, } \\
\text { Hyaluron }\end{array}$ & $\begin{array}{l}\text { It creates struc- } \\
\text { ture with living } \\
\text { cells, } \\
\text { Hard and soft tis- } \\
\text { sue scaffolds, } \\
\text { 3-dimensional } \\
\text { hydrogels, ceram- } \\
\text { ics and hydrogels. }\end{array}$ & $\begin{array}{l}\text { It can be operat- } \\
\text { ed at room tem- } \\
\text { perature. } \\
\text { They do not re- } \\
\text { quire thermo- } \\
\text { plastic materials. }\end{array}$ & $\begin{array}{l}\text { Distortion of cellular struc- } \\
\text { ture and loss of cellular } \\
\text { viability. }\end{array}$ \\
\hline
\end{tabular}

improves the quality of dental treatment and patient satisfaction. The 3D printers are becoming accessible and affordable, but the skill of operator and material cost must be taken into consideration. Safety and Health protocols must also be followed. Endodontic post-graduate programs must consider implementing the 3D printing into curriculums in the near future. Further research in this would revolutionize digital dentistry and also the clinical outcomes of treatments employing the $3 \mathrm{D}$ printed objects.
Conflicts of interest: Authors declared no conflicts of interest.

Financial support: None

\section{References}

1. Dawood A, Marti BM, Sauret-Jackson V, Darwood A. 3D printing in dentistry. British dental journal. 2015; 219(11):521.

2. Anderson, J. Wealleans, J., and Ray, J. (2018). Endodontic applications of 3D printing. Int. Endod. J. 2018; 51: 1005-1018 
3. Liu Q, Leu M C, Schmitt S M. Rapid prototyping in dentistry: technology and application. Int J Adv Manuf Technol. 2006; 29:317-35.

4. Abarna Jawahar et al, Applications of 3D Printing in dentistry - a review. J Pharm Sci. Res 2019; 11 (5):1670-1675

5. Nayar S, Bhuminathan S, Bhat WM. Rapid prototyping and stereolithography in dentistry. J Pharm Bioallied Sci. 2015;7:S216-S219.

6. Melchels FP, Feijen J, Grijpma DW. A review on stereolithography and its applications in biomedical engineering. Biomaterials. 2010;31:6121-30.

7. Rebong RE, et al. Accuracy of three dimensional dental resin models created by fused deposition modeling, stereolithography, and polyjet prototype technologies: a comparative study. Angle orthod.2018;88(3):363-369

8. 8. Zein I, Hutmacher DW, Tan KC, Teoh SH. Fused deposition modeling of novel scaffold architectures for tissue engineering applications. Biomaterials. 2002;23:1169-85.

9. Chen J, Zhang Z, Chen X, Zhang C, Zhang G, Xu Z. Design and manufacture of customized dental implants by using reverse engineering and selective laser melting technology. The Journal of prosthetic dentistry. 2014;112:1088-95.

10. Helena N Chia, Benjamin M Wu. Recent advances in $3 \mathrm{D}$ printing of biomaterials. Journal of Biological Engineering. 2015;9:4.

11. Cui X, Boland T. Human micovasculature fabrication using thermal inkjet printing technology. Biomaterials.2009; 30: 6221-7.

12. Kfir A, Telishevsky-Strauss Y, Leitner A, Metzger Z. The diagnosis and conservative treatment of a complex type 3 dens invaginatus using cone beam computed tomography (CBCT) and 3D plastic models. Int End Journal. 2013; 46,275-88.

13. Kim E, Kim K-D, Roh B-D, Cho Y-S, Lee S-J. Computed tomography as a diagnostic aid for extracanal invasive resorption. J Endod. 2003; 29, 463-5.

14. Ayar MK. Is a three-dimensional-printed tooth filling possible? Dent Hypotheses. 2016; 7:53-55.

15. Zenhnder MS et al. Guided endodontics: Accuracy of a novel method for guided access cavity preparation and root canal location. Int Endod J. 2016; 49:966 -72.

16. Kuhl S et al. Technical accuracy of printed surgical templates for guided implant surgery with the co DiagnostiX software. Clin Implant Dent Relat Res. 2015;17: e177-82.
17. Jacob GS. 3D Printing for education and training in Endodontics. Inside Dentistry. 2016; 12(1).

18. Tsukiboshi M (2002) Autotransplantation of teeth: requirements for predictable success. Dental Traumatology 2002; 18,157-80.

19. Vandekar M, Fadia D, Vaid NR, Doshi V (2015) Rapid prototyping an adjunct for autotransplantation of impacted teeth in the esthetic zone. J Clin Orthod. 2015; 49: 711-5.

20. Sureshchandra B, Roma M. Regeneration of dental pulp: A myth or hype. Endodontology. 2013; 25 (1):139-55.

21. Hung., et al. Water-based polyurethane 3D printed scaffolds with controlled release function for customized cartilage tissue engineering. Biomaterials. 2016; 83: 156-168. 